\title{
WOUND AND LOSS IN NAIPAUL'S INDIA: $A$ WOUNDED CIVILIZATION AND AN AREA OF DARKNESS
}

\author{
Babu Ram Khanal
}

\begin{abstract}
This study explores the pain and multifaceted loss in Naipaul's novels: India: a Wounded Civilization and An Area of Darkness. In the first part of this research, pain and loss of the aborigines have been exposed. It challenges the nationalist discourse of the India's progress. The second part, mapping culture through the novel is divided into two sections. The first section"India: A Wounded Civilization" deals with the condition of India in the post independent period. It claims that India has been wounded for many centuries of British Raj. The second section follows "An Area of Darkness." Naipaul assumes that India is still in darkness. People are living in illiteracy, ignorance and poverty. In addition to caste system practiced in different communities has shadowed the pure and mounted image of India. The last section is the conclusion of the research. It sums up the whole claims and textual analysis of the research.
\end{abstract}

Keywords: Colonization, Globalization, Invaders, Intellectuals, Mimicry, Bureaucrats.

\section{LAYING THE FOUNDATION}

They had been so wounded by the atrocities of slavery that by all means they wanted to get away from clutches of the white. (Voices of the Indian Diaspora, 305)

The condition of being marginalized, quest for a decent living and the realization of being othered has made different ethnic groups and aborigines unite and struggle for their rights, for the protection of their culture and identity, because the aborigines and ethnic group feel that they

1 Dr. Khanal is an Associate Professor, English Department, Saraswati Multiple Campus, Kathmandu, TU. 
have lost their culture, their language, their identity and their civilization has been wounded. This article tries to analyze the feelings and realizations and experiences of the characters and their loss in V.S. Naipaul's novelsIndia: A wounded civilization, and An Area of Darkness.

In these novels wound and pain of the characters have been explored and interpreted, and exposed in different locations and scenario. However, these pain do not confine only to physical wound and loss but go beyond.

Colonization, globalization and mimicry have destroyed, disfigured and distorted Indianness of India. They have bred wound and loss of millions of Indians. As Frantz Fanon agrees that colonization holds the natives in its grip, empties their brain, disfigures and destroys them. Fanon assumes that identity is a desire that human beings have constructed for recognition, association and protection which have been lost.

Rajagopalan Radhakrishnan, too has similar, feelings of being wounded and lost. He cites his son, who is living in the USA, feels isolated because he believes that he has lost his identity due to the loss of culture and race. Edward Said emphasizes that the cause of wound is because of West's construction of binaries, that is rich vs poor, advance vs backward, civilized vs barbarians. Terry Goldie (1994), too, has similar belief that the white European still take Indian as other and alien though they have been living their for centuries (234). Regarding the condition of being wounded and lost, Stuart Hall agrees that "the culture and root of every person play vital role in the construction of identity which he believes has been shadowed when people are in a diasporic state" (222).

Naipaul's novels- India: A Wounded Civilization and Area of Darkness expose the state of characters' wounded and isolated condition. Though three decades of India's independence were over, India is still languishing by many centuries of foreign rule. She hasn't yet found her own ideology of regeneration. This study tries to explore the wounds and losses due to the loss of culture, race, language and identity in the aforementioned Naipaul's novels, the characters in these novels come across several problems: crisis of identity, disappearance of their culture, class, racial discrimination and economic inequality.

Naipaul believes that India is still languishing. She is passing with illiteracy, backwardness and poverty. The western imported technology is not geo-based, so it does not match with the needs of majority Indians, India has failed to produce human resource with the highest skills and 
clearest vision. The novel narrates that India's intellect is wounded. It is of second rate and all progress is mere imitation and mimicry of the west. Naipaul writes

All the disciplines and skills that India seeks to exercise are borrowed. Even the ideas, Indians have the achievement of their civilization are essentially ideas given to them by European scholars, in the nineteenth century, India by itself could not have rediscovered or assesed its past. (116)

India remained fully dependent upon the west and it borrows alien academic discipline to understand its past. The centuries of British rules of India had adverse effect in its culture, economic development and civilization. India is still crippling without its own specific identity. She is not to be judged but is only to be experienced. In addition, western technical hegemony is another cause for which India is suffering. She has not developed her own technology so far which would have been simpler and beneficial for marginalized Indians. The intellectuals and the planners are more confused today than they were in the British rules. Naipaul retorts:

In their attempt to go beyond the old sentimental abstraction about the poverty of India, and to come in terms with the poor, Indians have to reach outside their civilization, and they are at the mercy then of every kind of imported ideas. The intellectual, confusion is greater now than in the days of British Raj. (105)

India's wounded civilization has been further exposed in Naipaul's explanation. He believes that intellectual Hindu civilization has been dominated by Muslim and European invaders. India has faced one obstacles after another "turning inward, revealing a wounded civilization". Naipaul cites Jagan, a traditional Hindu characters from R.K. Narayan's work, The Vendor of Sweets who is prosperous, follower of Gandhi and who never paid taxes because Gandhi had asked him not to pay the tax. His son goes to the USA to study creative writing though he doesn't study it at all. Instead he marries a Korean-American woman and comes back to India. He wants to set up a modern factory with American collaboration which will be an American invention. The couple lives and acts like American. However, their work annoys Jagan. He takes it as an intrusion of alien elements in Indian's life. He believes that all the modes of traditions are shattered. Jagan feels, he is lost and directionless. Jagan lives in a world which is 
chaotic, directionless, and which has no vision for the future. Naipaul views the situation thus: "... for the reasons comedy fails, the writer's fictional world collapses, they have both been damaged by the intrusion of alien elements. Shock after shock." (29) Jagan is not alone who is in confusion and directionless. There are many Indians living in despair. The entire India is experiencing loss.

There are wounds in the feelings and realization of people. Law and order of the country is mocked by the criminals and politicians. It is practised not according to the principle of the country but according to the whims of politicians. Politics is the handmaid of the criminals and internal structure is damaged completely. Judicial decisions are delayed and influenced by politicians. This was the case of India in the seventies and eighties. There were several wounds difficult to locate, diagnose and heal. N.S. Saksena defines the wounds thus:

One of the worse development in this period what is now called criminalization politics. Two of the worst states in this respect were Bihar and Punjab. Even the south which is much less criminal than the North was affected. Uttar Pradesh came somewhere in between. As Deputy Inspector General of Police in UP from 1960 to 1969 and as a chief of UP police in 1970 and 1971, I saw how criminals get the support of the politicians who pleaded for leniency to them in the matter of registration. (13)

These sort of losses and crisis lead to the issue of identity and complexities. Identity itself is a very complex, indefinable and amorphous term and it carries almost all aspects of culture and ethnicity, nation and politics. It is not natural rather a created aspect which can define who we are in simple way. Cornel West, in his essay, A Matter of Life and Death views identity in these words.

Identity is predicted on how you construct desire, and how you conceive death: desire for recognition, quest for visibility, the sense of being acknowledged a deep desire for association what Edward Said would call affiliation. It is longing to belong. (147)

At the individual level, identity answers the questions, who am I? And on the social level who are we in relation to others. It is a matter of constructed consciousness not the passive gift of history. Instead it is the 
product of interaction and experience, and it, by nature, keeps on changing according to time and space. It reflects not only the past but paves roads to the future. Therefore, it is not right and fixed entity but a fluid active process. Stuart Hall defines:

Cultural identity is a matter of becoming as well as 'being'. It belongs to the future as much as to the past. It is not something which already exists, transcending place, time history and culture, cultural identities come from somewhere, have histories, but like everything which is historical they undergo constant transformation. (112)

Even though identity is fluid and constantly changes, the natives/ ethnics undergo different mental and emotional crisis. They mostly have to face social problems of being substandard and thus the problem of alienation affects their consciousness. Due to the memories of their past, economic inequality, their visible existence in their homeland and the feeling of being nobody in their own place creates the loss of identity. Vijay Mishra (2007) calls this loss as psychology of dislocation (123).

Mapping culture Through the Novel

(a) India: A Wounded Civilization

The fictional presentation of wound and darkness undercuts the nationalist discourse about the progress of India, The discourse of progress has been found imaginative, confusing, chaotic and directionless. This research, therefore attempts to locate the authentic/grounded reality which looks different.

The novel gets the background from the emergency of 1975 when Naipaul had visited India the third time. What he saw and heard on this visit is described vividly in the novel which reinforced in him a conviction that India wounded by many centuries of foreign rule has not yet found an ideology of regeneration. Naipaul views the scenario thus:

Mimicry within mimicry, imperfectly understood idea: the second year girl student in the printing department not understanding the typographical exercise she had been set, playing with type like a child with a type writer avoiding in the name of design, anything like symmetry . . . there . . . there are times when the intellectual confusion of India seems 
complete and it seems impossible to get back to clarifying first principles. (111)

Colonial inferiority of Indians is another cause of India's confusion and directionless. The British presence in India from the early seventh century to mid-twenties caused a serious of loss in the arena of culture, language, religion politics and geography of the nation. In the beginning the British entered India as merchants of East India Company in the first decade of the seventh century. The company, having its promoters from London had to make much effort and struggle to establish its monopoly right of trade in India because Indian opposed British presence in India. Dale H. Hoiborg explains:

The English venture in India was entrusted to the East India Company which received its monopoly rights in 1600 . The company included group of London merchants attracted by Eastern prospects, not comparable to the national characters of the Dutch company. (9)

In course of time, the British merchants in India intervened in the politics of the government of India for faster promotion of their trade though Indians refused any political intervention by the outsiders. They employed the strategic imperial policy in order to accomplish the faster promotion of their trade to achieve this, the British merchants tempted the local Indians and slowly and gradually lifted to the further steps with the support of the local powers. Hoiberg states the British's strategic entrance to the Indian politics as:

At first the British were only one group of foreign readers among several, fortunate, to find in the Mughals, a firm government ready to foster trade. Their entry into politics was gradual, first as allies of country powers than as their virtual directors and only finally as master. At each step they were assisted by local powers who preferred British influence to that of their neighbors. (18)

When the British oppression was in extreme, a military war broke between the British troop and the Indian troops in the southern part of India. In 1757, a military force led by Robert Clive defeated the forces of the Nawab of Bengal and Introduced British Empire to India. Kumar assumes, "The situation became so serious that the British government was compelled to send a contingent of Gorkha soldiers to suppress the rebels" 
(230). This victory of Gorkha Battalion over the southern Indian troops transformed the East India Company from the association of traders to the rules. They directly began to exercise political sovereignty over a large land and people of India making a colonial post. Tuhiwai Linda Smith states, "Colonialism became imperialism's outpost, the fort and port of imperial outreach" (23). The nation then went in the hand of the outsiders. It was the beginning of the loss of political sovereignty of the Indians in India. Indians for the first time experienced the colonial governance ruled by the outsiders in their own homeland.

India is in constant trauma of one kind or the other. This trauma doesn't give Indians any time to pause and think objectively. Naipaul has exposed the reality which is chaotic and without the sense of historical continuity. He dissects Indian psyche and pinpoints the muddy thinking and mythologizing that is widely prevalent in the intellectual life of India. The novel could be seen as a critique of the blindness of Indians to the real world who prefer to live and judge themselves and others through the myopic glass of perceived high culture of centuries of rich civilization. Sashi Tharoor portrays the situation thus

. . . large dry full of ragged humans eking but a living from land which had too many pitiful scratching on its unyielding surface. There was starvation in Motihari not just the land did not produce for its tillers to eat but because it could not, under the colonialist laws, be entirely devoted to keeping them alive. Three tenth of every man's land had to be consecrated to Indigo, since the British needed cash crops more than they needed wheat. (50)

The Western hegemony is another cause of India's wounded civilization. West is simultaneously constructed as superior where as East as inferior. The sensuality, irrationality, primitiveness and despotism of the East construct the West as rational, democratic, progressive and so on. Not only, that the West always functions as the central and the East as marginal, other than simply through its existence confirms the West's centrality and superiority. Not surprisingly, the opposition that the West discourse about the East set up makes use of another basic opposition that the West is enlightened, rational, entrepreneurial, disciplined while the East is its feminine, opposition, irrational, passive, undisciplined and sensual. 
Antonio Gramci (1998), the Italian Marxist in the Basics used the term 'hegemony' as domination by consent the way the ruling class succeeds in opposing other classes with their apparent approval. In Gramci's analysis, the ruling class makes its own values and interests central in what it presents as a common neutral culture. The other classes accept that culture and become complicit in their own oppression and the result is a kind of velvet domination. Gramci puts, "The consent is historically caused by the prestige (and the consequent confidence) which the dominant group enjoys because of its position and fiction in the world of production" (88). Although Gramci's explanation of the power of ideology is less forceful than Althusser's it has the merits of allowing us to resist what he calls the 'hegemony'.

The self confidence of the colonizer's is further undermined by what Bhabha calls mimicry-the always slightly alien and distorted way-to which the colonized either out of choice or under duress will repeat the colonizer's ways and discourse. In mimicry in the by the colonizer sees himself in a mirror that slightly but effectively distorts the image that subtly and unsettlingly others his own identity. The characters, in V.S. Naipaul's novel, India: A Wounded Civilization, have similar feelings of western hegemony from which they are unable to escape. Naipaul explains the feelings:

India's poverty was a special and I got the impression that as a Gandhian he did not want to see anyone spoiling it. The old man disliked machine; he told me he had heard that people to the West and began to turn against them as well, and though in a famine region and though asking people for votes he strongly disapproved of having piped water and electricity were morally bad ... No more fetching healthy water from the well, no more corn grinding with the old fashion quern. The good old ways were going, every thing was being westernized. (138)

India's confusion and directionless is seen not only in India's feeling but also in India's way of working. India is supposed to drift a pace with the progress of science and technology and hew out all the out dated traditional thoughts, feelings, culture and traditions.

Caste system still prevails in India. Untouchables are still assumed an obstruction in the way of India's development. Child marriage and puberty marriage, is still in practice in some communities. Hierarchy 
between low caste and high caste, rich and poor have become major issues of modern India. Crime, juvenile delinquency, unrest among youths and suffering of the aged are the real issues of today in the industrialized India. In addition law and order of the country is mocked every part. Polygamy and polyandry system practised in Toda,Kota and the Nair community has shadowed the heightened image of India.

The Sati system prevalent in Hindu community as a glory of Hindusim or Talaq system practised in Muslim community is outdate, old fashioned, awkward and primitive. This has further wounded India's civilization. C.N. Shankar Rao expresses:

The Sati system made the wife to be not only attached to the husband as long as he lived, but even after his death, because a Sati could never conceive of a second marriage or a second husband. Hence, on the death of the husband, the wife had either to live chastely renouncing all the joys of life or to follow her husband by jumping into the funeral pyre . . . a Muslim can divorce his wife as per the Muslim law without the intervention of the court. In Talaq, the husband has the right to dismiss his wife by repeating the dismissal formula thrice, the Talaq may be affected either orally or by making some pronouncement or writing by presenting talaqnama. (337/345).

Thus, the Indian civilization passes with number of losses, undecidability and confusion. The Sati and Talaq system practised among Hindu and Muslim communities have lowered down the pure and mounted image of India. The riots between the Hindus and Muslims, Hindus and Christians, for the sake of religious identity, rituals and norms have pushed the sacred crown of India into chaos. The notion of secularism has been threatened by many in secular elements. Naipaul's novel India: A wounded civilization reveals wide spread wounds and the pain people have in the post-independent India.

The following chapter researches into An Area of Darkness.

b. An area of darkness

The background of the novel An Area of Darkness is 1964 when Naipaul had first visited his ancestral home, India. India has not been able to develop an efficient mechanism of bureaucrats until then. Naipaul 
portrays his own experience of nuisance in India upon reaching the customs. Seventeen years of post-independence period has not brought any significant change in India's progress. 'You have your liquor permit?" "You have your transport permit? ..." (20) were unnecessary irritating questions asked him by the security personnel upon reaching Bombay. These sorts of questions embittered Naipaul. The system of having a permit was a difficult, complicated process that Naipaul was fed up and started moving here and there enquiring the person he met in the scorching sun. He explains the situation in this way:

At last I reached the office. It was a long low room at the ground level hidden from the scorching sun and as dark as a London basement, but warm and dusty with the smell of paper, which was everywhere, on shelves rising to the grey ceiling, on desks, on chairs, in the hands of clerks, in the hands of the khaki-clad messengers. Folders had grown dog eared, their colors faded, their spines abraded to transparency, their edges limp with reverential handling; and too many were attached pink slips, equally faded, equally limp, marked URGENT, VERY URGENT, or IMMEDIATE. (94)

This was the case of post independent India. Until 1964, no system was developed, no government official fulfilled their responsibility. It was the land of chaos and confusion.

The novel is divided in three parts, the first part is a narration of different events and activities. The narrator is one of the characters himself. The first part is the core of the novel. It undercuts the constructed discourse of India's progress. The resting place for the imaginations are like shadows. This remains only in fantasy and a man who has been moving onwards cannot catch the imagination in reality. India was an area of darkness. He compares the life of India to Trinidad, a colony of Britain, and the life of Indians in India in the post independence period. The community residing in Trinidad have given whole Indian existence. But the Indian community, though seemed self-contained, was perfect. They did not need sweepers to clean because they cleaned themselves. They know that they defecate in proper places only. In addition, the Indian community in Trinidad had their own carpenters, masons and cobblers. It was almost an independent community though away from their ancestor's home. But, in India people 
were much depended. They never thought of their responsibility. Naipaul quotes thus:

... the India that had produced so many of the persons and things around me was featureless, and I thought of the time when the transference was made as a period of darkness, darkness which also extended to the land, as darkness surrounds a hut at evening, though for a little way around the hut, there is still light. The light was the area of my experience, in time and place. And even now, though time has widened, though space has contracted and I have travelled lucidly over at area which was to me the area of darkness ... (32)

Yet, Naipaul was still hopeful that a little away from the hut, he sees light.

Caste system is a great obstacle in the development of a progressive India. The aphorism of Sanskrit:

$$
\begin{aligned}
& \text { त्राहमणोऽस्य मुखमासीद् वाहू राजन्य: कृतः । } \\
& \text { उरु तदस्य यद् वैश्यः पदभ्यां शुद्रो अजायत । }
\end{aligned}
$$

\section{(Brahamano-sya mukha-maa sida baahu rajanya: krita: Uru tadasya yada baisya: padavyam sudro ajayata. )}

Brahmins were born from the mouth of brahma, chhetrys from the arms

Baishyas, came from the legs while untouchable emerged from the feet.

(Qtd in Four Veds: Purush sukita 10/90/12)

Brahmins are born from the mouth of Brahma, and they are assigned to perform worship, to please gods and deities; the Kshatry's from the arm and their task is to fight against the enemy and protect the nation. Similarly, the Vaishays were born from the thigh and they are assigned to deal with commerce, trade, and finally the Sudra (untouchables) were born from the feet and their task is to serve) - is well practised in Indian community, especially in majority Hindus. This brutal division of labor on the ground of the caste has created greatest hierarchy among the people of the country. A chamar was always a leather worker and a sweeper was always a latrine cleaner. Likewise a Brahmin has to go through the sacred thread ceremony and he has to go to Kashi Banaras for study. Similarly jobs are assigned to 
others on the basis of their caste. The characters in the "area of darkness" had expressed the sadness of the disparities brought about by the caste system. Raman, a chamar died in imagination of pursuing other profession, may be, pursued by high class. His desire of having other prestigious jobs could not materialize in his life. On the other hand, in Trinidad caste had no meaning. They could read in the newspaper, in the textbook about India where the system of untouchability exists. Naipaul writes about the system:

In Trinidad caste had no meaning in our day to day life; the caste we occasionally played at was no more than an acknowledgement of latent qualities; the assurance it offered was such as might have been offered by a palmist or a reader of hand writing. In India it implied a brutal division of labor and at its center, lay the degradation of the latrine cleaner. (36)

India is, on the other hand, an area of imagination but not a real country, states Naipaul (44). Because of this deep rooted caste system, India is still languishing as a poorest country in the world. In Trinidad and in other parts of Europe and America such disparities on the basis of caste are not seen. In India a Brahmin or a Kshatry can not be found in the business of leather.

The Indian English is the mimicry of the West and it is nothing but just like fantasy. Buildings, railways, a system of administration, the intellectual discipline of the civil servant, the economists all are mimicry only. India has not developed her own technology, her own way of thoughts and actions. Even the scientists believe in astrology rather than straight forward action. The security personnel are not an exception to this. Mimicry is found to their gait, look, manner and taste. This sort of colonized mentality destroys, distorts Indianness of India. Frantz Fanon puts it thus:

Colonization is not satisfied merely with holding a people in its grip and emptying the native's brain of all form and content. By a kind of perverted logic, it turns to the past of the oppressed people, and distorts disfigures and destroys it. (154)

Naipaul believes that India has been mutilated destroyed and disfigured by the West. There is still the effect of Eurocentricism.

Naipaul draws a comparison between colonial India and colonial Trinidad. In Trinidad, there is even more freedom than in India. Everyone 
is free to follow his own religion, system etc. There is no imposition of one religion upon the other religion. Upon his reaching India Naipaul goes to the cave of Amarnath, the Eternal Lord which is ninety miles north of Srinagar. He speaks about his joy and that of the other pilgrims they climb the Himalayas and try to get inside a cave. Naipaul calls it like a typical Indian bazaar. Then he cites further anecdotes of young couple who have become the victim of the poverty of India and who were his companions in the pilgrimage. An American girl Laraine in her better off position came to India and was living in the Ashram. Then she joined the pilgrimage to Amaranth. In Srinagar she met Rafiq, a poor Muslim musician. They spend a great deal of time together and the Christian girl married Rafiq who was not of her status. But they got detached. It is the native's poverty that compelled Laraine get divorce from Rafiq and go back her home, America. Naipaul explains their quarrel thus.

... no fulfillment on their faces, no fatigues, they were both hysterical. They were quarrelling and their rage was real. Presently they exchanged blows. The faces of both were already marked. She kicked him. He groaned and slapped her. She cried out, swung her bag at him, kicked him again, and tumbled down the brambly slope. ... She went her ashram; and then she left India. He wrote, she replied; then his letters were returned unopened. Her parents had been separated and lived in different countries ... (192)

The union between Rafiq and Laraine was broken because of poverty. Rafiq was unable help her retain her status in India. Because of this inability, tussle broke between the couple and at last she left her Indian husband.

The British had exploited the country completely. Therefore, Indian had to unite and move against the British imposition in India. The British were forced to leave India. Indian's quest for freedom was materialized. Yet, the hangover of British presence occupied their mind. Nonetheless, the case of Trinidad was different. Even a child knew that Trinidad was a British colony though there was no effect upon them because they were, in course of time, being tuned up with the system. There people of many races appropriated English rule, English institutions and the English language without questioning. 
Because of their swaggered nature and dominating manner, British Raj could not be present in Indians mind. Indians always took them as colonizer. For Indians England and Englishness was always a fantasy. Indians recognized the English character as a creation of fantasy. They could never appropriate themselves as Mughals though Mughals, too, were foreigners. Naipaul views:

In India the Mughals were also foreigners, with fantasies as heady; they ruled as foreigners; but they were finally absorbed in India. The English, as Indians say, again and again did not become part of India, and in the end they escaped back to England. (212)

Similar view about English people has been expressed by Jamaica Kincaid. Because of the arrogant nature and dominating manner of English people, they are forced to leave the country where they ruled for hundred years, taking every advantage, imposing their Eurocentric nature and othering the people of the Third World Countries. Kincaid puts it thus:

. . . the English have become such a pitiful lot these days, with hardly any idea what to do with themselves now that they no longer have one quarter of the earth's human population bowing and scraping before them. They do not seem to know that this empire business was all wrong and they should at least, be wearing sack cloth and ashes in token penance of the wrong committed, the irrevocableness of their bad deeds ... what went wrong ... no place could ever really be England, and nobody who did not look exactly like them would ever be English, ... the English hate each other and they hate England, and the reason they are so miserable now is that they have no place else to go and nobody else to feel better than. (92)

The Britisher's desire of being colonizer was the major cause of their fall. They had to go back to England because of their exploitative nature.

English language, has created confusion among the Indians. Because Britishers could create confusion, they have been able to cause psychological damage by the continued official use of English language. It has made easy for the administrator to be present himself separate from 
the ordinary people. Not only that, the clerk using English in government office is found always helpless because he does not properly understand English himself. He feels as if he is passing his working life in a sub-world of dim perceptions. But any Indian would be quick, inventive and efficient in Hindi. Also, Hindi, Assamese or other languages spoken in India is understood by half of the country and one can travel to any part of the country without any trouble.

The confusion does not get limited only in the use of English to offices but it is used in the newspaper to the Indian and non-Indian. The Indians were given least priority when the Westerner's news came in bold letter covering front pages. An example to this regard runs as under:

Five hundred deaths from cholera in Calcutta are reported in a news- brief in an Indian newspaper. The death of twenty children merely requires to be stated .... The death of sixteen miners in Belgium, in the same newspaper, is big news.... The peasants in the collector's court attend with open mouths to the drama of debates in a language they can't understand.... (qtd. in Naipaul. 424)

India s weakness was exposed in 1962. It was found that India was not becoming strong in military power; no readiness to protect the country from the foreigners. Indians were still in confusion. They were quarrelling for power, chair. Nepotism and favoritism had blinded them.

Having got every advantage of India's weakness, Chinese launched massive simultaneous attack in North Eastern Frontier Area (NEFA), and Ladakh in Arunachal Pradesh, Gorkhas, armed with knives only, were sent up to Ladakh to fight against the Chinese enemy. The political leader gave big speeches. The Chinese invasion continued for a week or more. The country's unpreparedness was mocked. Emergency was imposed in the country. Nothing was done in order to retaliate. People didn't know the fact why their country was attacked. 'It is dangerous to have an inoculation against cholera during an epidemic, the doctor remarked in satirical way.

All India radio did not talk about the war. Anyone if $\mathrm{s} /$ he wanted to know about the development, s/he had to listen to the Chinese or Pakistan Radio. However, Chinese had unilateral decision. "They declared a ceasefire and promised a withdrawal of the soldiers from Indian invaded 
area" (260). Instead of resisting the attack, the Indian side chanted mantras, gave big speeches on ethics and morality and condemned the Chinese using abusive language that "They ate pork, brows puckered, ate dogs, rats and eyes popped" (264).

Naipaul expresses his pain for being separated from his ancestral home. Yet, he is contended to be a colonial without a past without ancestors. He exposes that his grand parents had left for Trinidad as indentured labor, almost in late nineties. On his first visit to India, Naipaul goes his ancestor's home in Uttar Pradesh which is inhabited by Brahmins like Dube and Tiwaris. The Brahmin's village has her own culture, customs and tradition. He meets Ramchandran who was tilling the land which his grand father had bought from the earning of Trinidad. Ramchandran has developed illmotives. He wants to get some land, establish his right upon the land which is not his own. Shocked, he leaves India to a mood itself reproach, Naipaul says, " So it ended, in futility and impatience a gratuitous act cruelty, selfreproach and flight" $(277)$.

India remains an area of darkness for Naipaul. He expresses his bitter experiences after his year's journey to different parts in India. He does not fail to criticize the chaos and confusion of the flight in which he was travelling. No system was working in the flight. One had to go to report early at the airport to leave by midnight. The condition of the lavatory was horrible. In addition, the passengers, time and again threw papers upon him. Because of the frequent disturbances of the children passengers, he couldn't sleep at all. He views the condition thus:

Paper fell into my lap in the aircraft. Long blond hair and a pair of big blue eyes appeared above the seat in front of me, and tiny feet pattered against the small of my back .... What's my crazy luck that every time I go to sleep on a plane and wake up I see children. The child behind me is going to get hurt. The little bastard is kicking my kidney in. (278)

People had been so undisciplined that they would start annoying anyone they find. Norms and values were mocked inside the airplane, too. The air passengers were troubled by other children passengers and there was no one to stop them from hitting others. 
India remained an illusion for him. He felt that he was homeless, without the past, without ancestors. The condition of homelessness was much felt when Ramchandran made every attempt to tempt him in order to establish his right upon his ancestral property. His thoughts and feelings about India were undercut by the fiction which is real. For Naipaul the fictional world does not become imaginary but something true.

\section{CONCLUSION: Wounds and Mimicry}

The condition of directionless and confusion has led India into chaos. This is seen in people's way of thinking and working. This thinking has created a great crisis in culture, race, and customs of India. Naipaul thinks that India has not been able to develop and generate her own ideology that would differentiate her from the mimicry of the West. He believes that India's intellect is second rate and all progress is mere imitation and mimicry of the West.

India is still languishing. She is passing through illiteracy, backwardness and poverty. The western imported technology could not work to fulfil the needs of marginalized people because it was not geo based. The centuries of British rule in India had adverse effect in her culture, economic development and civilization. India was still crippling without its own specific identity and ideology

V S Naipaul thinks that India's civilization is wounded. Western technological hegemony has languished her. He believes that intellectual Hindu civilization has been dominated for too long first by the Muslim invaders and second by the British rule. After the burst of optimism following independence, India has faced one obstacle after another. The country has almost been lawless. There are wounds in the feelings and realization of the people, law and order of the country is mocked by the criminal politicians. It was practised and implemented not according to the principle of the country but according to the whim of politicians. Not only this, politics has become handmaid of the criminals and internal working environment is totally damaged. Judicial system is delayed and affected by corruptions.

V.S. Naipaul views that India has not been able to develop herself. She hasn't found her own ideology of regeneration. Instead India is plunged in mimicry within mimicry. 
Hinduism has become the cause of India's sterility, stagnation and impotency. According to Naipaul, the Hindu society which Gandhi had appeared to ennoble during the struggle for independence had begun to disintegrate with the rebirth and growth that had come with independence. In addition, colonial inferiority of Indian's is another cause of India's confusion and directionless which has ultimately wounded India s civilization.

The British presence in India from early seventeenth century to mid-twentieth century caused a series of loss in the area of culture, language, religion, politics and geography of the nation. Not only this, the British merchant in India intervened in the politics of India for faster promotion of their trade though Indians refused any political intervention by the outsiders.

Caste system is a great obstacle in the development of progressive India. The brutal division of labour on the ground of the caste has created greatest hierarchy among the people of this great country. A chamar was always a leather worker and a sweeper was always a latrine cleaner.

The British had exploited the country in all forms. Therefore, Indians had to unite and move against the British imposition in India. The Britishers were forced to leave India. India's quest for freedom was materialized. Yet, the hangover of British presence occupied their mind. Because of their swaggered nature and dominating manner. British Raj could not be present in Indian's mind. They always viewed them (Britishers) as outsiders and colonizers.

The colonizer's language- English- has created confusion among the Indians. Because Britishers could create confusion, they have been able to cause psychological damange by the continued official use of English language. It has made them administrator to be present himself separate from the ordinary people and thus create hierarchy. This state of confusion and creation of hierarchy has wounded Indian civilization.

India remains An Area of Darkness for Naipaul. He exposes his bitter experience after his years' journey to different parts of India. He doesn't hesitate to comment the chaos and confusion of the flight to which he was a traveller. Not with standing, India remained an illusion for him. He felt that he was homeless without the past, without ancestors. 
In this way, the events and characters in the novels: An Area of Darkness and India: A Wounded Civilization along with the events in the colonial and post independence history of India are the examples of wound and loss. The wounds and crisis of identity inherited by the characters in the novel justify the title of the research. In all cases wound and loss have been explored and narrated objectively and have been seen, experienced and connected from the British Raj to present India.

\section{WORKS CITED}

Bhabha, H.K. (1994). The location of culture. London: Routledge.

Bertens, H. (2003). The basics. New York: Routledge.

Fanon, F. (2001). "The Fact of Blackness." The post-colonial studies reader, edited by Bill Ashcroft et al. Routledge, 2001, pp. 323-26.

Goldie, Terry (1989). "Representation of the Indigene". The post colonial studies reader, edited by Bill Aschroft et al., New York: Routledge, pp. 232-236.

Gramci, A. (1998). "Hegemony." Literary theory: Anthology, Oxford, Blackwell, p. 88.

Hall, S. (1990). "Identity: Community, Culture, Difference." Cultural identity and diaspora, edited by J. Rutherford, Lawrence and Wishart. Lawrence, pp. 222-237.

Hoiberg, D.H. (2003), “Indian History Modern.” Encyclopedia Britannica. Inc.

Kincaid, J. (2001). "A Small Place." The post-colonial studies reader, edited by Bill Ashcroft et.al. Rutledge, pp. 92-94.

Kumar, S. (2001). "Gandhi and the Diaspora Question: Histories, Texts and Readings." In diaspora, edited by Makrand Paranjape. Indialog Publications, pp. 68-78.

Mishra, V. (2007). "Traumatic Memory, Mourning and V.S. Naipaul." The literature of Indian diaspora, Routledge, pp. 106-132.

Mullo, A. (2007). Voices of the Indian diaspora. Motilal Banarsidass Publishers.

Naipaul, V.S, (1964). An area of darkness. Vintage Books.

Naipaul, V.S, (1977). India: Wounded civilization. New York: Picador. 
114 WOUND AND LOSS IN NAIPAUL'S INDIA, A WOUNDED ...

Radhakrishnan, R. (1997), "Is the Ethnic "Authentic" in the Diaspora"? Diasporic mediations between home and location. University of Minnesota Press. pp.203-214.

Rao, C.N.S. (2004). "Marriage in India". Sociology primary principle. Delhi: S. Chand and Company, pp. 334-347

Said, E. (1994). Culture and imperialism. Vintage.

Saksena, N.S. (1993) "Subash Ghishing and Gorkhaland." India towards anarchy. Abhinov Publication, pp. 92-95.

Smith, L.T. (2004). Decolonizing Methodologies. University of Otago Press.

Tharoor, S. (1989). The great Indian novel. India: Penguin.

West, C. (1995). "The Identity in Question." The cultural politics of difference. edited by John Rajchman, Routledge, pp. 147-172. 